\title{
Erratum to: Mesenchymal Stem Cells in Synovial Fluid Increase After Meniscus Injury
}

\author{
Yu Matsukura MD, Takeshi Muneta MD, PhD, \\ Kunikazu Tsuji PhD, Hideyuki Koga MD, PhD, \\ Ichiro Sekiya MD, PhD
}

Received: 16 December 2013/ Accepted: 18 December 2013/Published online: 3 January 2014

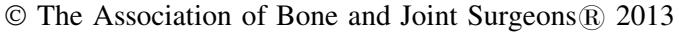

\section{Erratum to: Clin Orthop Relat Res DOI 10.1007/s11999-013-3418-4}

In the published study by Matsukura and colleagues, the scale of the Y-axis in Figure 6 is incorrect. The scale of the $\mathrm{Y}$-axis should be ranging from 0 to 1200 .

The authors apologize for this error.
The online version of the original article can be found under doi:10.1007/s11999-013-3418-4.

\section{Y. Matsukura, T. Muneta, H. Koga}

Department of Joint Surgery and Sports Medicine, Graduate

School, Tokyo Medical and Dental University, Tokyo, Japan

\section{K. Tsuji}

Department of Cartilage Regeneration, Graduate School,

Tokyo Medical and Dental University, Tokyo, Japan

\section{Sekiya ( ( )}

Center for Stem Cell and Regenerative Medicine,

Tokyo Medical and Dental University, 1-5-45 Yushima,

Bunkyo-ku, Tokyo 113-8519, Japan

e-mail: sekiya.arm@tmd.ac.jp

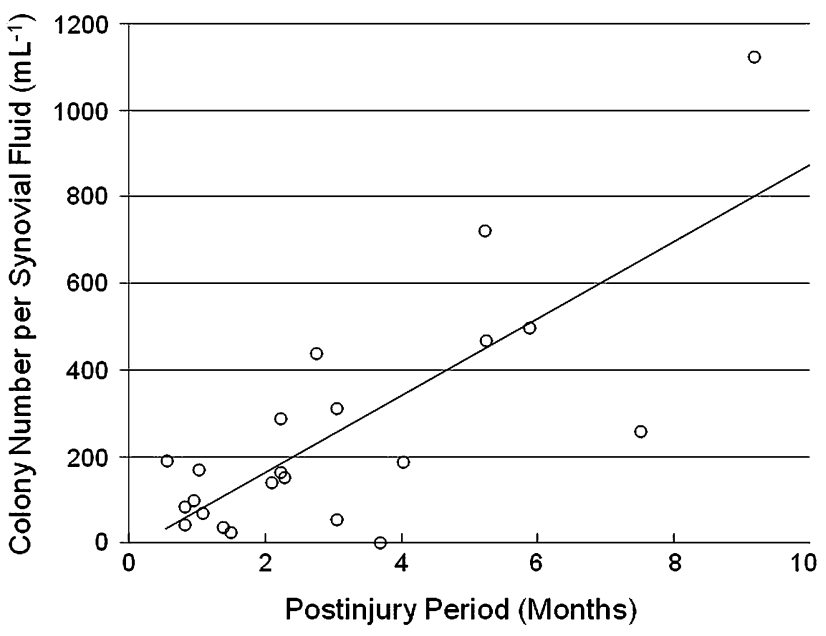

Fig. 6 Colony number per synovial fluid $\left(\mathrm{mL}^{-1}\right)$ was positively correlated with postinjury period $(\mathrm{n}=22, \mathrm{r}=0.773, \mathrm{p}<0.001)$. 